\title{
UPAYA MENJADIKAN MADRASAH SEBAGAI LEMBAGA PENDIDIKAN UNGGUL
}

\section{M.Nur Hasan}

\section{Fakultas Ilmu Tarbiyah dan Keguruan (FITK) UIN Walisongo}

drmnurhasan@yahoo.com

Efforts Muslims to realize the quality of Islamic Education Institutions have long coveted, to be able to give birth to a superior madrasah model that can compete with general education institutions.

Madrasah on behalf of himself as superior schools and madrasah model should be recognized by the government and the public, not by the madrasah / school itself. Because excellence means having a value more than the other schools or Madrasahs, and certainly worth it not only can be seen from the physical aspect, but also other aspects that determine.

Characteristics of a superior madrasah at least has three aspects, 1). Input, how the selection process for potential students is be done. 2) The process, which includes the ability of teachers, adequate facilities learning, curriculum, skill for language of Indonesian, Arabic, and English is absolutely necessary, teaching methods, which make students become active and creative, which is accompanied by freedom in expressing thoughts and imagination, also extar activities program, as well as extensive cooperation network. 3) Out put, an ability of graduates produced deemed superior, when they have been able to develop intellectual, emotional and spiritual potention of where they are located.

Therefore, madrasah should have the advantage to be proud of the school and the community, which includes comparative advantage and competitive advantage.

Keywords : Islamic Education, Madrasah, Superior, 


\section{A. Latar Belakang}

Pada masa sekarang banyak Madrasah yang menamakan dirinya sebagai lembaga pendidikan Islam unggulan. Namun tidak jelas kriteria dan standar yang diberlakukan pada masing-masing Madrasah. Untuk mengatasi problem ini, maka sangat diperlukan standarisasi yang ditetapkan oleh pemerintah atau institusi yang memiliki kewenangan untuk memberikan panilaian terhadap performansi Madrasah sebagai suatu lembaga pendidikan Islam. Hal ini sangat urgen sekali untuk dibahas dalam tulisan ini, karena kualitas layak tidaknya predikat unggulan bagi suatu Madrasah akan mempengaruhi mutu dan kualitas pendidikan Islam dibanding dengan pendidikan atau institusi pendidikan pada umumnya. Mutu Madrasah hendaknya dapat sejajar dan lebih unggul dari pendidikan umum unggulan lainnya.

Pada saat keadaan yang sama, langkah-langkah awal pemerintah untuk mendukung adanya Madrasah unggulan dan meningkatkan mutu dan kualitas Madrasah, pemerintah di bawah naungan Kementerian Agama melahirkan kebijakan-kebijakan dengan melahirkan Madrasah model. Inspirasi adanya Madrasah model berawal adanya lulusan-lulusan Madrasah dan kualitas pendidikan di Madrasah masih rendah dibandingkan dengan pendidikan umum lainnya. Oleh sebab itu kebijakan tersebut terealisasi sehingga dari segi manajemen, administrasi, personal dan lulusannya dapat mengembangkan dirinya melalui bantuan fasilitas, beasiswa pendidikan lanjutan bagi guru-guru dan lain-lain.

Madrasah yang mengatasnamakan dirinya sebagai sekolah unggulan dan Madrasah model harus diakui oleh pemerintah dan masyarakat, bukan oleh Madrasah/sekolah itu sendiri. Karena keunggulan berarti memiliki nilai yang lebih dibanding dengan sekolah/Madrasah yang lain dan tentunya nilai itu tidak hanya dapat dilihat dari aspek fisik, melainkan juga aspek-aspek lain yang sangat menentukan. Misalnya proses pembelajarannya ataupun output yang dihasilkan. Begitupun juga sekolah yang mendapat predikat Madrasah model dari pemerintah harus mampu menunjukkan dirinya sebagai sekolah yang layak dan pantas untuk dicontoh oleh sekolah atau Madrasah lainnya.

Bila dicermati dari kebijakan ini, bahwa harus ada implementasi baik Madrasah unggulan untuk melibatkan teknologi pendidikan, salah satunya teknologi pembelajaran. Sekolah dan guru sebagai pelaku utama dalam penerapan Madrasah unggulan dituntut inovatif dan kreatif untuk menggunakan perangkat teknologi, sehingga mendukung kualitas pembelajaran. Namun, sebagai guru madrasah sangat jarang guru-guru atau madrasah menggunakan teknologi untuk meningkatkan keunggulan Madrasah.

\section{B. Rumusan Masalah}

Berdasarkan latar belakang di atas, maka rumusan masalah dalam penulisan karya ilmiah ini adalah bagaimana upaya Pendidikan Islam menjadikan Madrasah sebagai lembaga Pendidikan unggul? 


\section{Tujuan Penulisan}

Berdasarkan rumusan masalah di atas, maka tujuan penulisan karya ilmiah ini adalah bagaimana upaya Pendidikan Islam menjadikan Madrasah sebagai lembaga pendidikan unggul.

\section{Madrasah Unggulan}

\section{Pengertian Madrasah/Sekolah Unggulan}

Dalam Kamus Besar Bahasa Indonesia dijelaskan bahwa yang dimaksud dengan unggul adalah lebih tinggi, pandai, kuat, dan sebagainya daripada yang lain; terbaik; terutama. sedangkan Keunggulan artinya keadaan unggul; kecakapan, kebaikan dan sebagainya yang lebih dari pada yang lain. ${ }^{1}$

Secara terminologis sekolah unggul dalam perspektif Kementerian Pendidikan Nasional adalah sekolah yang dikembangkan untuk mencapai keunggulan dalam keluaran (output) pendidikannya. Untuk mencapai keunggulan tersebut maka masukan (input), proses pendidikan, guru dan tenaga kependidikan, manajemen, layanan pendidikan, serta sarana penunjangnya harus diarahkan untuk menunjang tercapainya tujuan tersebut. ${ }^{2}$

Dengan demikian Sekolah/Madrasah unggulan dapat didefinisikan Sekolah yang dikembangkan dan dikelola sebaik-baiknya dengan mengarahkan semua komponennya untuk mencapai hasil lulusan yang lebih baik dan cakap daripada lulusan sekolah lainnya.

\section{Latar Belakang Munculnya Madrasah Unggulan}

Sejak diberlakukannya Undang-undang No.20 Tahun 2003 tentang Sistem Pendidikan Nasional yang menempatkan Madrasah sebagai bagian dari subsistem pendidikan nasional. Madrasah pun dituntut untuk melakukan inovasi dan pembaharuan diri, baik secara kelembagaan maupun dari sisi mutu output-nya. ${ }^{3}$

Mutu output yang diharapkan telah terkonsep dalam UUD 1945 pasal 31 ayat 3 yang menyebutkan bahwa pemerintah mengusahakan dan menyelenggarakan satu sistem pendidikan nasional yang meningkatkan keimanan dan ketaqwaan serta akhlaq mulia. Konsep ini memiliki tujuan untuk mencerdaskan kehidupan bangsa di mana menaruh harapan dan cita-cita bahwa suatu lembaga pendidikan harus mampu membawa dan mengarahkan siswanya untuk memiliki iman, taqwa dan akhlaq mulia. Sehingga mereka cerdas baik secara intelektual, moral maupun spiritual. Madrasah sebagai lembaga pendidikan memiliki tugas menyiapkan dan mengembangkan sumber daya manusia berkualitas di bidang IMTAQ dan IPTEK yang perlu dibarengi dengan terobosan dan inovasi yang up to date guna memfasilitasi lahirnya output yang unggul.

Pada kenyataannya, Madrasah/Sekolah unggulan ternyata mendapat dukungan dari masyarakat untuk menyekolahkan anaknya di Madrasah-Madrasah yang unggul dengan tanpa

1 Peter Salim dan Yenny Salim, Kamus Bahasa Indonesia Kontemporer (Jakarta: Modern English Press, 1991) hlm, 1685.

2 Muhammad, "Konsep Pengembangan Madrasah Unggul”, Kreatif, Vol. 4, No. 1 (Januari 2009), hlm 39.

3 Ibid., hlm 35. 
menghiraukan berapapun biaya yang dikeluarkan. Sehingga mendirikan Madrasah yang baik (unggul) menjadi lahan bisnis yang menggiurkan di samping misi sosial tertentu yang diemban oleh yayasan yang mendirikan Madrasah-Madrasah unggul. ${ }^{4}$

Dalam konteks lembaga pendidikan atau sekolah, istilah unggul dapat dilekatkan pada Madrasah yang pada akhirnya terdapat adanya keinginan dan gairah baru di lingkungan organisasi pendidikan seperti Madrasah untuk inovasi menjadikan sekolahnya menjadi lebih baik kualitasnya dan unggul dari sekolah lainnya. Usaha ini menuntut Madrasah bukan hanya harus memiliki cita-cita dan keinginan saja, tapi Madrasah agar selalu memiliki kebutuhan berprestasi dan terus berprestasi sehingga tercapai keunggulan dalam segala aspeknya.

\section{Karakteristik Madrasah Unggulan}

Secara umum Madrasah yang dikategorikan unggul harus meliputi tiga aspek. Ketiga aspek tersebut adalah:

\section{a. Input}

Daniel Goleman, dalam bukunya, menyebutkan bahwa kemampuan mengenal diri dan lingkungannya adalah kemampuan untuk melihat secara objektif atau analisis, dan kemampuan untuk merespon secara tepat, yang membutuhkan kecerdasan otak/Intelligence Quotien (IQ) dan kecerdasan emosional/Emotional Quotien (EQ). Di samping itu, kecerdasan spiritual/Spiritual Quotien (SQ) calon siswa hendaknya dapat terukur saat seleksi siswa baru. Dengan demikian, tes seleksi siswa baru hendaknya dapat mengukur ketiga aspek kecerdasan atau bahkan dapat mengukur berbagai kecerdasan/multy intellegence. Sehingga, tes seleksi siswa baru tujuannya tidak semata-mata untuk menerima atau menolak siswa tersebut tetapi jauh ke depan untuk mengetahui tingkat kecerdasan siswa. Dengan data tingkat kecerdasan siswa tersebut dapat digunakan sebagai dasar untuk menentukan proses pembinaannya dan bahkan dapat untuk menentukan target atau arah pendidikan di masa depan. ${ }^{5}$

Untuk Madrasah dapat menyeleksi siswa oleh sekolah dengan sistem seleksi yang sangat ketat. Selain seleksi bidang akademis, juga diberikan persyaratan lain sesuai tujuan yang ingin dicapai sekolah. Misalkan tes IQ, prestasi belajar dari jenjang pendidikan sebelumnya, tes kesehatan, kemampuan membaca al-Qur'an, wawasan keagamaan. ${ }^{6}$

Sungguh suatu keunggulan luar biasa bila suatu Madrasah sudah mampu selektif dalam proses penerimaan siswa baru. Calon siswa nantinya dapat dibina, dibimbing dan belajar sesuai dengan tingkatan kecerdasan mereka, yang nantinya diarahkan untuk menghasilkan lulusan yang unggul.

\section{b. Proses}

Proses belajar-mengajar sekolah unggul ini setidaknya berkaitan dengan kemampuan

4 Agus Maimun dan Agus Zaenul Fitri, Madrasah Unggulan Lembaga Pendidikan Alternatif di Era Kompetitif (Malang: UIN Maliki Press, 2010), hlm 26.

5 Petrus Trimantara, "Sekolah Unggulan: Antara Kenyataan dan Impian" Jurnal Pendidikan Penabur, Vol. 6, No.08 (Juni 2007), hlm 7.

6 Halfian Lubis, Pertumbuhan SMA Islam Unggulan di Indonesia (Badan Litbang dan Diklat Departemen Agama Republik Indonesia), 79. 
guru, fasilitas belajar, kurikulum, metode pembelajaran, program ekstrakurikuler, dan jaringan kerjasama.

1) Kemampuan guru.

Sekolah unggul harus memiliki guru yang unggul juga. Artinya, guru tersebut harus profesional dalam melaksanakan proses belajar-mengajar. Adapun kompetensi guru yang memungkinkan untuk mengembangkan suatu lembaga pendidikan yang unggul adalah: a) Kompetensi penguasaan mata pelajaran; b) Kompetensi dalam pembelajaran; b) Kompetensi dalam pembimbingan; c) Kompetensi komunikasi dengan peserta didik; dan d) Kompetensi dalam mengevaluasi. ${ }^{7}$

Untuk mengembangkan kompetensi ini guru harus selalu rajin-rajin membaca, belajar terus menerus, selalu up to date membaca fenomena sosial yang terjadi dimasyarakat sehingga pembelajaran bersifat faktual dan kontekstual. Pembelajaran dapat berjalan efektif sehingga mencapai tujuan yang ingin dicapai.

Pembelajaran bisa dikatakan efektif, bila guru mampu memberikan pengalaman baru bagi siswanya, membentuk kompetensi siswa, serta melibatkan peserta didik dalam perencanaan pelaksanaan dan penilaian pembelajaran. Siswa harus didorong untuk menafsirkan informasi yang disajikan oleh guru sampai informasi tersebut dapat diterima oleh akal sehat. Misal salah satunya dengan tanya jawab. ${ }^{8}$

Di samping itu, guru harus ikhlas memberi pelayanan kepada siswa dalam belajar, dalam artian siswa merasa nyaman berada dalam bimbingan guru tersebut. Guru harus mampu menilai hasil balajar ranah kognitif, psikomotorik dan afektif siswa dan dapat mengetahui siapa dan ranah apa saja yang belum dikuasai oleh siswa, sehingga guru tepat memberi pencerahan kembali kepada siswanya.

Nah dengan demikian Guru yang profesional, dalam pembelajaran harus menempuh empat tahap, yaitu: Pertama, Persiapan dalam arti yang luas adalah segala usaha misalnya membaca, kursus, pelatihan, seminar, diskusi, lokakarya yang dilakukan oleh guru dalam rangka mengembangkan profesionalitasnya. Persiapan dalam perngertian yang sempit adalah kegiatan pembuatan program kerja guru yang meliput penyusunan kegiatan pembelajaran selama satu tahun, program semester, penyusunan silabus dan pembuatan rencara pelaksanaan pembelajaran (RPP) sesuai dengan kurikulum. Kedua, Pelaksanaan, bahwa guru harus fleksibel, artinya pelaksanaan program disesuaikan dengan kondisi dan situasi peserta didik. Fokus pelaksanaan pembelajaran adalah pengalaman peserta didik, baik pengalaman kognitif, afektif, maupun psikomotorik. Ketiga, Penilaian perlu dilakukan terhadap kedua belah pihak, baik guru maupun siswa. Penilaian harus dilakukan secara objektif dan transparan. Keempat, Refleksi. Tindakan yang dilakukan dengan memikirkan aktivitas pembelajarannya dan melaksanakan pembelajarannya berdasarkan tujuan yang jelas atas dasar pertimbangan moral dan etika. ${ }^{9}$

7 Trimantara, "Sekolah Unggulan:",hlm 8.

8 Asmaun Sahlan, Mewujudkan Budaya Religius di Sekolah (Malang: UIN-MALIKI Press, 2010), hlm 45.

9 Trimantara, "Sekolah Unggulan:", hlm 8. 
Guru harus mampu tanggap terhadap aktivitas pembelajaran dengan melakukan tindakantindakan yang dibutuhkan siswa sehingga tujuan pembelajaran akan tercapai.

Proses pendidikan Islam tidak akan berhasil dengan baik tanpa peran guru yang professional, terutama pada proses pembelajaran saat guru menggunakan metode dan memberikan materi. Peranan guru sangat penting tersebut bisa menjadi potensi besar dalam memajukan atau meningkatkan mutu pendidikan. Guru yang benar-benar berlaku professional dan dapat mengelola dengan baik, tentunya mereka akan makin semangat dalam menjalankan tugasnya, bahkan rela melakukan inovasi-inovasi pembelajaran untuk mewujudkan kesuksesan pembelajaran peserta didik. Namun jika mereka terlantar akibat tindakan pimpinan mereka justru bisa menjadi penghambat serius terhadap proses pendidikan. Sikap guru ini sangat tergantung pada kualitas manajemen personalia. ${ }^{10}$

2) Fasilitas belajar.

Sekolah unggul harus dilengkapi dengan fasilitas yang mewadahi. memiliki sarana dan prasarana yang mewadahi bagi siswa untuk menguasai ilmu pengetahuan dan teknologi.

3) Kurikulum.

Sekolah unggul tidak harus menggunakan kurikulum yang standar internasional. Kurikulun nasional dengan berbagai penyempurnaan sesuai kebutuhan perkembangan siswa pun cukup baik. Terutama dari segi bahan, misalnya bidang IPA dan PAI, masih terlalu menekankan bahan-bahan klasik yang memang penting, tetapi kurang memasukkan bahan dan penemuan modern yang lebih dekat dengan situasi teknologi saat ini. Misalnya mengkaitkan materi-materi dari kedua mata pelajaran tersebut. Di samping itu, penguasaan bahasa Arab, bahasa inggris dan bahasa Indonesia mutlak diperlukan. Sehingga siswa dapat mengkomunikasikan gagasan dan pengetahuannya kepada orang lain secara sistematis dengan menggunakan kedua bahasa tersebut. Perpaduan kedua kurikulum itu akan sangat membantu dalam menghasilkan generasigenerasi masa depan yang lebih unggul.

4) Metode pembelajaran.

Sekolah yang unggul harus menggunakan metode pembelajaran yang membuat siswa menjadi aktif dan kreatif yang disertai dengan kebebasan dalam mengungkapkan pikirannya.

5) Program ekstrakurikuler

Sekolah unggul harus memiliki seperangkat kegiatan ekstrakurikuler yang mampu menampung semua kemampuan, minat, dan bakat siswa. Keragaman ekstrakurikuler akan membuat siswa dapat mengembangkan berbagai kemampuannya di berbagai bidang secara optimal

6) Jaringan kerjasama.

Sekolah unggul memiliki jaringan kerjasama yang baik dengan berbagai instansi, terutama instansi yang berhubungan dengan pendidikan dan pengembangan kompetensi siswa. Dengan adanya kerjasama dengan berbagai instansi akan mempermudah siswa untuk menerapkan

10 Mujamil Qomar, Manajemen Pendidikan Islam (Surabaya: Erlangga, 2007), hlm 129. 
sekaligus memahami berbagai sektor kehidupan (life skill). ${ }^{11}$

\section{c. Output}

Sekolah unggul harus menghasilkan lulusan yang unggul. Keunggulan lulusan tidak hanya ditentukan oleh nilai ujian yang tinggi. Indikasi lulusan yang unggul ini baru dapat diketahui setelah yang bersangkutan memasuki dunia kerja dan terlibat aktif dalam kehidupan bermasyarakat.

Kemampuan lulusan yang dihasilkan dirasa unggul, bila mereka telah mampu mengembangkan potensi intelektual, potensi emosional, dan potensi spiritualnya di mana mereka berada. ${ }^{12}$

\section{Tujuan dan Kedudukan Sekolah Unggul}

1. Wawasan iptek yang mendalam dan luas.

2. Motivasi dan komitmen yang tinggi untuk mencapai prestasi dan keunggulan.

3. Kepekaan sosial dan kepemimpinan.

4. Disiplin yang tinggi yang ditunjang kondisi fisik yangext-indent: Wawasan iptek yang mendalam dan luas.

5. Motivasi dan komitmen yang tinggi untuk mencapai prestasi dan keunggulan.

6. Disiplin yang tinggi yang ditunjang kondisi fisik yang prima. ${ }^{13}$

\section{E. Upaya Pendidikan Islam Menjadikan Madrasah Sebagai Lembaga Pendidikan Unggul}

Pengembangan pendidikan Islam dapat terealisasi melalui adanya kebijakan-kebijakan yang dikeluarkan oleh pemerintah. Institusi yang melahirkan kebijakan-kebijakan yang mendukung program Madrasah unggulan dan Madrasah model ini adalah Departemen Agama.

Madrasah sebagai suatu institusi pendidikan harus mampu mengembangkan mutu dan keunggulan pendidikan. Madrasah yang mengenalkan dirinya sebagai sekolah unggul, harus beda dari pada sekolah lainnya. Madrasah harus memiliki keuggulan yang layak dibanggakan oleh sekolah dan masyarakat. Dalam hal ini dikenal dua jenis keunggulan, yaitu;

\section{Keunggulan Komparatif}

Keunggulan komparatif adalah keunggulan yang sudah disediakan, dimiliki tanpa perlu adanya suatu upaya. Kekayaan alam yang dimiliki oleh suatu wilayah adalah contoh nyata keunggulan komparatif. ${ }^{14}$

Dalam konteks lembaga pendidikan, keunggulan komparatif menekankan pada keunggulan kaitannya dengan sumber daya yang disediakan, dimilki tanpa perlu adanya suatu upaya.

11 Trimantara, “Sekolah Unggulan:”,hlm 9.

12 Ibid.

13 http://saef-swordofgod.blogspot.com/2012/05/makalah-tentang-sekolah-unggul.html

14 Cahya Suryana, Mutu dan keunggulan pendidikan, dalam http://csuryana.wordpress.com (29 Desember 2012), 1. 
Misalkan suatu Madrasah dibandingkan dengan Madrasah lainnya memiliki fasilitas belajar yang diperoleh dari bantuan dari pemerintah, sedangkan sekolah di sekitarnya belum menerima bantuan fasilitas belajar. Nah sekolah ini memiliki keunggulan komparatif.

\section{Keunggulan Kompetitif}

Keunggulan kompetitif adalah keunggulan yang timbul karena ada suatu upaya yang dilakukan untuk mencapainya. Keunggulan kompetitif terkait dengan daya saing suatu produk yang relatif mapan sehingga mampu memasuki pasar tertentu dengan tingkat harga dan kualitas sesuai kebutuhan penggunanya. Produk yang memiliki keunggulan kompetitif biasanya didukung oleh pelayanan memadai sehingga memiliki daya saing dibandingkan dengan produk yang berasal dari sumber lain. ${ }^{15}$

Madrasah atau sekolah yang memiliki keunggulan kompetitif akan terus mengejar prestasinya sehingga mampu bersaing dengan sekolah lain, walaupun sudah mendapat bantuan dari pemerintah sekolah unggulan ini tetap dan terus berusaha meningkatkan kualitas keunggulannya, baik dalam hal manajemennya maupun outputnya. Pelayanan terhadap siswa dikelola dengan baik sehingga mereka dapat belajar dalam keadaan kondusif. Lulusan yang berkualitas akan dicari oleh masyarakat untuk diberdayakan potensinya yang diperoleh ketika disekolah.

Tantangan kehidupan saat ini lebih mengutamakan keunggulan kompetitif dibandingkan keunggulan komparatif. Keunggulan komparatif menekankan pada keunggulan kaitannya dengan sumber daya yang disediakan. Sedangkan keuntungan kompetitif bersandar pada penguasaan IPTEK serta informasi. Atas dasar pemahaman tersebut, yang dimaksud dengan 'keunggulan/excellence' pada istilah 'Center for Excellence' adalah jenis keunggulan kompetitif yaitu keunggulan yang diraih melalui suatu usaha.

Sedangkan mengembangkan Madrasah unggul merupakan satu aktivitas yang kompleks karena berkaitan dengan pengembangan sebuah organisasi sebagai wadah terhimpunnya komunitas yang memiliki latar belakang yang beragam. Membangun budaya unggul dalam sebuah organisasi, termasuk budaya unggul dalam lingkungan Madrasah memerlukan proses dan waktu yang panjang.

Mengembangkan keunggulan dalam sebuah sekolah/Madrasah melalui pendekatan budaya organisasi berarti mengorganisasi beragam manusia dan melebur mereka dalm satu pikiran yang terarah ke pembuatan produk dan layanan terbaik, pemuasan pelanggan sepenuhnya dan pemeliharaan warga organisasi itu sendiri. Berikut ini upaya-upaya yang mendukung untuk mengembangkan organisasi Madrasah dalam mencapai keunggulan, di antaranya:

a. Visi untuk unggul

Visi unggul menjadi demikian sentral posisinya dalam pengembangan Madrasah unggul, sebab tanpa visi, mimpi dan gambaran tentang masa depan sebuah organisasi sulit untuk berjalan lancar. Dengan visi unggul sebuah Madrasah selalu mengupayakan arah masa depan yang lebih 
baik, memiliki SDM yang religious, terampil mandiri dan berwawasan ke depan. ${ }^{16}$

b. Kepemimpinan yang inspiratif'

Organisasi membutuhkan kepemimpinan yang profesional tapi rendah hati, visioner dan inspiratif. Kepemimpinan yang mampu mengubah dan memperbarui organisasi serta dapat membangkitkan semangat dan memberikan inspirasi kepada segenap komunitas organisasi yang dipimpinnya.

c. Kolaborasi dan Kolegilitas

Kolaborasi mencakup semua aktivitas yang dilakukan oleh komunitas organisasi pembelajar dan layanan pendukung eksternalnya bersama-sama berbagi informasi dan ide-ide, merencankan bersama, dan bersama-sama pula membuat keputusan dan partisipasi dalam pengembangan organisasi. Kolegialitas lebih menekankan interaksi interpersonal yang dibangun melalui keterbukaan atau keyakinan. ${ }^{17}$

d. Membangun rasa saling percaya

Dalam sebuah organisasi terdapat team work yang tidak mungkin bekerja sama kecuali atas dasar nilai saling mempercayai atau mampu menjadikan diri sebagai anggota yang pantas dipercayai. Di lembaga pendidikan seperti Madrasah juga diperlukan semangat saling mempercayai dalam bekerja sama agar tercipta iklim organisasi yang kondusif bagi komunitas Madrasah.

e. Membangun jaringan sosial (social capital)

Untuk menjadi sekolah organisasi unggul, Madrasah perlu memiliki kecerdasan sosial. Kemampuan sebuah Madrasah untuk tetap survive tidak hanya ditentukan oleh seberapa besar kemmpuannya dalam menghasilkan output yang berkinerja dan berprestasi unggul, tetapi juga ditentukan oleh koneksinya dengan stakeholders, dan para pengguna jasa. Yaitu salah satunya tetap menjaga kepercayaan stakeholders terhadap keunggulan Madrasah dengan mempertahankan dan meningkatkan citra serta kinerja organisasi Madrasah unggul.

Dengan merealisasikan beberapa bentuk pendekatan-pendekatan pengembangan pendidikan Islam melalui Madrasah unggulan maka diharapkan akan melahirkan lulusan yang bisa menampilkan citra diri sebagai sosok makhluk Tuhan yang didalam dirinya terdapat potensi rasional (nalar), emosi dan spiritual. Tiga dimensi keunggulan dalam perspektif Islam mencitrakan sosok manusi utuh. Lembaga pendidikan yang terlalu banyak menekankan pentingnya nilai akademik, kecerdasan otak atau IQ saja, mengabaikan kecerdasan emosi (EQ) yang mengajarkan integritas, kejujuran, komitmen, visi, kreativitas, ketahanan mental, kebijaksanaan, keadilan, prinsip kepercayaan, penguasaan diri atau sinergis menjadikan pendidikan kehilangan ruhnya. ${ }^{18}$

Dalam perspektif pendidikan ideal belumlah cukup untuk menggambarkan keutuhan sosok manusia. Sebab dalam diri manusia terdapat satu aspek penting lainnya yaitu potensi spriritual. Kecerdasan yang membuat manusia berbuat kebaikan, kebenaran, keindahan, dan kasih sayang dalam hidup, Kecerdasan untuk menempatkan prilaku dan hidup manusia dalam kontek 16 Muhammad, "Konsep Pengembangan Madrasah Unggul”,hlm 45.

17 Ibid, hlm 46.

18 Ibid., hlm 41. 
makna yang luas dan lebih kaya. Kecerdasan spiritual yang ditanamkan melalui pendidikan akan memberikan bekal kepada peserta didik sehingga mampu menjawab keprihatinan dirinya tentang apa arti menjadi manusia, apa makna dan tujuan puncak dari hidup manusia. ${ }^{19}$

Bila sekolah mampu mengorientasikan tiga kecerdasan tersebut berarti sekolah/Madrasah unggul telah mengakomodasi dan mengarahkan sisi kemanusiaan peserta didik agar memiliki intelektualitas, spiritualitas, moralitas, sosialitas, rasa, dan rasionalitas dalam kehidupannya. Sehingga output yang dihasilkan akan mampu hidup serasi dan seimbang dengan lingkungan keluarga, anggota masyarakat, alam, dan juga dengan Tuhan

Menurut Mujtahid, Dosen Fakultas Tarbiyah UIN Malang Langkah strategis untuk melakukan pengembangan Madrasah dan sekolah Islam unggulan tersebut memerlukan upaya sebagai berikut: ${ }^{20}$

\section{Membangun Mindset Secara Kolektif}

Untuk mengembangkan mutu Madrasah dan sekolah Islam unggulan membutuhkan pandangan, cita-cita, imajinasi, nilai-nilai keyakinan yang kuat dan kolektif. Walaupun seringkali muncul sebuah perbedaan (konflik) di Madrasah atau sekolah Islam, yang cukup mengganggu kepentingan institusi yang akan dikembangkan bersama-sama. Tatkala tumbuh konflik kepentingan, antara kepentingan individu dan institusi, maka yang harus dimenangkan adalah kepentingan institusi. Aspek kepentingan institusi harus dibangun secara kolektif dengan orientasi yang sama. Kepentingan institusi harus dikedepankan daripada kepentingan individu.

Mindset yang perlu dibangun pada lembaga pendidikan Islam unggulan adalah menanamkan keyakinan dan tekad bersama kepada seluruh warga sekolah atau Madrasah. Mereka digerakkan untuk memperjuangkan keunggulan institusi, dengan cara mengimplementasikan visi, misi, tradisi, orientasi dan mimpi-mimpinya ke depan selalu disosialisasikan oleh pimpinan di semua tingkatan melalui berbagai bentuk publikasi, baik secara lisan, tulisan dan bahkan media lainnya secara terus menerus ke seluruh warga Madrasah atau sekolah.

Mindset secara kolektif tersebut menjadi modal sosial (social capital) bagi pengembangan kultur akademik di Madrasah atau sekolah Islam unggulan ke depan. Madrasah atau sekolah unggulan membutuhkan lingkungan akademik yang handal dan tekad bersama. Inspirasi dan semangat inilah yang harus dibangun dan dikembangkan untuk meningkatkan mutu akademik dan institusinya.

Pengembangan cita dan kultur akademik sesungguhnya selaras dengan visi dan misi Madrasah dan sekolah Islam unggulan. Kata "keunggulan" menyiratkan adanya kekuatan dan kelebihan yang tidak dimiliki oleh lembaga pendidikan lain pada umumnya. Ciri dan karakteristik tersebut harus dijaga sekaligus dihidupkan agar persepsi masyarakat tidak salah tangkap. Istilah unggulan bukan hanya sekedar nama dan label, akan tetapi merupakan gambaran utuh yang di dalamnya terdapat suasana akademik yang unggul, kultur lembaga (budaya organisasi) yang

19 Ibid., hlm 42.

20 http://www.uin-malang.ac.id/index.php?option=com_content\&view=article\&id=2224:pengembanganMadrasah-dan-sekolah-unggulan\&catid=35:artikel-dosen \&Itemid=210 
efektif, kualitas pembelajaran (learning quality) yang kreatif dan inovatif, serta internalisasi nilainilai keislaman yang aktual dalam setiap perilaku, sikap dan perbuatan sehari-hari di Madrasah dan sekolah Islam.

\section{Menciptakan Inovasi secara Terus Menerus}

Keunggulan lembaga Madrasah dan Sekolah Islam sesungguhnya terletak pada inovasinya. Inovasi merupakan usaha dan kerja nyata untuk mencari dan membuat hal baru demi meraih kemajuan dan keunggulan bagi lembaga pendidikan itu sendiri. Inovasi harus didasarkan pada kebutuhan idealita dan realita agar lembaga Madrasah dan sekolah Islam itu terus maju dan berkembang.

Inovasi tiada henti harus terus menerus digerakkan untuk memacu kualitas dan daya saing yang tinggi. Inovasi tidak saja diperlukan untuk selalu menyempurnakan kondisi Madrasah, tetapi juga penting untuk membangun keutuhan (holistika) tujuan pendidikan Madrasah dan sekolah Islam. Usaha dan kerja nyata itu ditempuh secara serentak, menyeluruh dan padu di antara beberapa elemen yang ada di Madrasah dan Sekolah Islam. ${ }^{21}$

Bentuk inovasi itu misalnya, perbaikan atau penambahan sarana fisik, akademik, tenaga guru dan karyawan, perekrutan siswa dan seluruh aspek yang ada. Inovasi lainnya misalnya menciptakan kultur Madrasah atau sekolah Islam berbasis bilingual, mentradisikan hafalan alqur'an, menggerakkan pusat seni dan olah raga, dan seterusnya. Modal seperti inilah yang harus dituangkan dalam visi dan orientasi Madrasah dan sekolah Islam unggul itu.

Melalui usaha demikian dimaksudkan agar Madrasah dan sekolah Islam unggulan dapat menawarkan sesuatu yang baru, yang khas dan memiliki keunikan yang diperhitungkan oleh banyak orang. Tugas ini membutuhkan seorang pemimpin yang imajinatif dan didukung oleh warga sekolah atau mdrasah yang dedikatif dan istiqamah. Tanpa modal itu inovasi sulit diwujudkan dalam kerangka operesional di lapangan.

\section{Memanfaatkan Teknologi Informasi}

Menurut hemat penulis, untuk memajukan Madrasah dan sekolah Islam yang merata dan berkualitas membutuhkan energi pikiran, tenaga dan usaha yang tiada henti. Madrasah dan sekolah Islam unggulan saatnya mengembangkan pembelajaran berbasis digital, selain yang sudah ada, guna mengefektifkan program dan kegiatan pendidikan yang lebih maksimal.

Pendidikan Madrasah dan sekolah Islam unggulan jangan sampai tertinggal di bidang teknologi informasinya. Dengan pemanfaat IT tersebut para siswa dapat belajar lebih intensif, disamping melalui sistem reguler dan kurikuler. IT dimanfaatkan sebagai sumber belajar yang mudah dan berjangkauan luas, tanpa hambatan waktu dan tempat.

Untuk menciptakan mutu layanan akademik, menurut hemat penulis dapat kembangkan sistem digital di sekolah atau Madrasah. Hampir semua aktivitas akademik melibatkan internet, sehingga program-program sekolah atau Madrasah dapat berjalan secara sinergis antara unit satu

21 http://www.uin-malang.ac.id/index.php?option=com_content\&view=article\&id=2224:pengembanganMadrasah-dan-sekolah-unggulan \&catid=35: artikel-dosen \&Itemid=210 
dengan unit-unit lainnya. Melalui proses digital ini, upaya untuk memajukan Madrasah atau sekolah sangatlah mudah diukur dan dirasakan oleh para pengguna. ${ }^{22}$

Kurikulum sekolah unggul harus memiliki tingkat fleksibilitas yang tinggi dan cukup representative, esensial, multivalensi dan menarik yang tercermin dalam topik bahasan dengan kriteria sebagai berikut: Suatu topik dalam kurikulum harus diperlukan oleh pefective, develop, accelerate dan essential.

Dari segi ukuran muatan, sekolah yang menamakan unggulan kebanyakan hanya diukur dari kemampuan intelektual akademis semata. Mestinya Sekolah mampu meningkatkan kualitas kepandaian dan kreativitas sekaligus menggunakan sumber daya yang dimiliki untuk mendorong prestasi anak didik secara optimal, tidak hanya kemampuan akademis saja tapi juga mengembangkan potensi psikis, etik, moral, religi, emosi, spirit, kreativitas dan intelegensi.

Seleksi input sekolah unggulan masih sulit dilaksanakan secara obyektif sesuai aturan yang telah ditetapkan. Hal ini disebabkan karena masih terdapat toleransi input bagi orang tua peserta didik yang berpengaruh dalam masyarakat.

Selama ini yang terjadi sekolah unggulan dimonopoli oleh pemegang otoritas pendidikan, seperti Kemendiknas. Sekolah unggulan diterapkan sekedar menciptakan prestasi anak didik, kurikulum dirancang sarat muatan, diajar guru berkualitas, dengan sarana-prasarana yang bagus, tapi biayanya sangat mahal. Padahal Sekolah unggulan kemungkinan dapat dicapai bila seluruh sumber daya Sekolah dimanfaatkan secara optimal. Mulai dari tenaga administrasi, pengembang kurikulum, tenaga pendidik, termasuk masyarakat harus dilibatkan secara berdaya guna. Karena semua sumber daya itu akan dapat menciptakan iklim dan kultur yang mampu membentuk keunggulan Sekolah.

Madrasah juga harus ada dukungan dari masyarakat sehingga menjadikan madrasah tersebut menjadi unggul karena madrasah tumbuh dari masyarakat dan dikembangkan oleh masyarakat. Madrasah mampu memenuhi hajat masyarakat akan pendidikan yang diperlukannya. Islami yaitu madrasah yang berciri khas agama Islam dalam suatu lingkungan kondusif yang mampu menciptakan anak bangsa menjadi seorang muslim yang beriman dan bertaqwa kepada Allah swt., serta berakhlak mulia. Berkualitas, yaitu madrasah yang mampu mencetak anak bangsa sebagai seorang muslim yang memiliki kemampuan dan keterampilan yang cukup serta sanggup menghadapi tantangan zaman.

Madrasah adalah institusi pendidikan Islam yang memberi pencerahan kepada anak bangsa melalui proses penyelenggaraan pendidikan sejalan dengan tujuan pendidikan nasional. Dalam hal ini institusi pendidikan Islam (perguruan Islam) khususnya madrasah memiliki tujuan untuk menghasilkan manusia muslim yang menghayati ajaran agama. Madrasah merupakan lembaga pendidikan Islam yang mempunyai karakter yang tidak hanya melaksankan tugas pendidikan dan pengajaran agama, tetapi juga memberikan bimbingan kepada masyarakat. Madrasah dapat menyiapkan peserta didik dalam sains dan teknologi, namun tetap dengan

22 http://www.uin-malang.ac.id/index.php?option=com_content\&view=article\&id=2224:pengembanganMadrasah-dan-sekolah-unggulan\&catid=35: artikel-dosen \&Itemid=210 
identitas keislamannya.

Walaupun Madrasah merupakan Sekolah yang berbasis keagamaan. akan tetapi, Madrasah dalam mengembangkan keunggulannya dengan menggunakan teknologi yang menunjang perkembangan Madrasahnya, yakni Kepala Madrasah bisa menfasilitasi Madrasahnya dengan sarana-saran yang berbau teknologi.

\section{F. Kesimpulan}

Madrasah unggulan mampu mengubah citra Madrasah menjadi lebih baik dan bisa menunjukkan kualitasnya dikalangan lembaga pendidikan pada umumnya. Program yang dicanangkan pemerintah ini merupakan langkah positif untuk mensejajarkan kualitas Madrasah dengan sekolah umum, baik manajemennya maupun output yang dihasilkan, sehingga memilki nilai lebih yang selalu dicari lulusannya dan didamba-dambakan masyarakat.

Pada dasarnya, munculnya Madrasah unggulan dilatar belakangi oleh masalah yang sama, yaitu masih rendahnya mutu pendidikan Islam, terutama masalah output yang dihasilkan dan kualitas manajemen yang ada di Madrasah. Dari inilah, pemerintah melakukan langkah awal dengan mengeluarkan kebijakan-kebijakan yang mendukung adanya Madrasah model. Seperti menyekolahkan guru-guru Madrasah hingga tingkat S2 dan menyediakan fasilitas-fasilitas laboratorium dan lain-lain. Setelah proyek ini jalan dan sukses menjadi Madrasah percontohan bagi Madrasah-Madrasah lainnya (Madrasah swasta), Madrasah-Madrasah tersebut bangkit untuk bisa berkembang seperti Madrasah model negeri tersebut. Sehingga tidak menutup kemungkinan Madrasah swasta dapat menjadi Madrasah unggulan.

\section{G. Saran}

Perkembangan dunia di era globalisasi ini memang banyak menuntut perubahan kesistem pendidikan nasional yang lebih baik serta mampu bersaing secara sehat dalam segala bidang. Salah satu cara yang harus di lakukan bangsa Indonesia agar tidak semakin ketinggalan dengan negara-negara lain adalah dengan meningkatkan kualitas pendidikannya terlebih dahulu.jadi kepala Madrasah marus mengetahui perkembangan di era globalisa dalam hal pencapaian/ mutu pendidikan yang baik.

Dengan meningkatnya kualitas pendidikan berarti sumber daya manusia yang terlahir akan semakin baik mutunya dan akan mampu membawa bangsa ini bersaing secara sehat dalam segala bidang di dunia internasional. Sehingga menjadi Madrasah unggul sangat baik untuk terlaksana untuk menjadikan Madrasah yang unggul dalam berprestasi dan berakhlakul karimah. 
$88 \mid$ M. Nurh Hasan

\section{Bibilografi}

Lubis, Halfian. Pertumbuhan SMA Islam Unggulan di Indonesia. Badan Litbang dan Diklat Departemen Agama Republik Indonesia, 2002.

Maimun, Agus dan Agus Zaenul Fitri. Madrasah Unggulan Lembaga Pendidikan Alternatif di Era Kompetitif. Malang: UIN Maliki Press, 2010.

Muhammad. "Konsep Pengembangan Madrasah Unggul”, Kreatif, Vol. 4, No. 1, Januari, 2009.

Qomar, Mujamil. Manajemen Pendidikan Islam. Surabaya: Erlangga, 2007.

Sahlan, Asmaun. Mewujudkan Budaya Religius di Sekolah. Malang: UIN- MALIKI Press, 2010.

Salim, Peter dan Yenny Salim, Kamus Bahasa Indonesia Kontemporer. Jakarta: Modern English Press, 1991.

Siregar, Imran. Efektifitas Penyelanggaraan Madrasah Model: Studi tentang MAN 2 Model Padangsidempuan. Jakarta: Puslitbang Pendidikan Agama dan Keagamaan, th.

Suryana, Cahya. Mutu dan keunggulan pendidikan, dalam http://csuryana.wordpress.com. 29 Desember 2012.

Trimantara, Petrus. "Sekolah Unggulan: Antara Kenyataan dan Impian”, Jurnal Pendidikan Penabur, Vol. 6, No.08, Juni, 2007.

http://saef-swordofgod.blogspot.com/2012/05/makalah-tentang-sekolah-unggul.html. akses 5 Januari 2013.

http://www.uinmalang.ac.id/index.php?option=com_content\&view=article\&id=2224:penge mbangan-Madrasah-dan-sekolah-unggulan \&catid=35: artikel-dosen $\&$ Itemid=210. Akses 5 Januari 2013 